\title{
Tomboro: Praktik mandi uap untuk ibu nifas berdasarkan budaya Suku Muna
}

\author{
Diah Indriastuti ${ }^{1^{*}}$, Tahiruddin Tahiruddin ${ }^{2}$ \\ 1,2 Program Sarjana Keperawatan, Sekolah Tinggi Ilmu Kesehatan Karya Kesehatan, Indonesia \\ *Coresponding Author: nsdiahindri@gmail.com
}

\begin{abstract}
Abstrak
Pendahuluan: perawatan kesehatan pada ibu nifas penting untuk dijaga dengan tujuan mencegah masalah kesehatan. Permasalahan kesehatan yang sering dialami pada ibu nifas adalah mengenai kebersihan diri dan keseimbangan cairan yang memicu kejadian infeksi saluran kencing bahkan infeksi post partum. Metode: Penelitian ini adalah penelitian kualitiatif dengan pendekatan ethnografi. Hasil: penelitian ini digambarkan dalam 2 tema yaitu perawatan dan perlengkapan. Simpulan: perawatan kesehatan ibu nifas secara budaya telah dilakukan secara turun temurun oleh masyarakat Suku Muna yang sampai saat ini masih dilakukan. Penerapan perawatan budaya atau etnocaring pada praktik tomboro memiliki prinsip yang sama dengan Ilmu kesehatan modern dengan proses mandi uap dan aromatheraphy dari rempah daun yang digunakan
\end{abstract}

Kata kunci: Tomboro; mandi uap; suku muna; ibu nifas

\section{Tomboro: Steam bath practice for postpartum mothers based on Muna Culture}

\begin{abstract}
Introduction: health care for postpartum mothers is important to be maintained with the aim of preventing health problems. Health problems that are often experienced by postpartum mothers are about personal hygiene and fluid balance which triggers urinary tract infections and even postpartum infections. Methods: This research is a qualitative research with an ethnographic approach. Results: this study was described in 2 themes namely care and equipment. Conclusions: postpartum maternal health care is culturally carried out from generation to generation by the Muna people, which is still being conducted to this day. The application of cultural or ethnocaring treatments to the practice of tomboro has the same principles as modern health science with the process of steam baths and aromatherapy of the herbs used.
\end{abstract}

Keywords: Tomboro; steam bath; Muna Tribe; postpartum mothers

How to Cite: Indriastuti, D \& Tahiruddin, T. (2021). Tomboro: Praktik mandi uap untuk ibu nifas berdasarkan budaya Suku Muna. NURSCOPE: Jurnal Penelitian dan Pemikiran Ilmiah Keperawatan, 7 (1), 6-12

\section{PENDAHULUAN}

Masa nifas merupakan masa setelah 2 jam dari lahirnya plasenta sampai dengan kurang lebih 40 hari (Danefi, 2016; Rini \& D, 2017). Ibu nifas akan mengalami berbagai adaptasi terutama adaptasi fisik dari masa kehamilan menjadi masa nifas diantaranya organ perkemihan (Aziz, Fauzi, Sanif, \& Theodorus, 2009; Gusrianty, Astuti, Hartinah, \& Susanti, 2016). Kebutuhan cairan ibu hamil meningkat dengan signifikan untuk produksi cairan amnion, peningkatan jumlah darah, pertumbuhan janin dan kebutuhan tubuh ibu, jumlah cairan tersebut akan berkurang secara bertahap melalui persalinan (Fauzia \& Sutejo, 2012; Rini \& D, 2017).

Permasalahan yang dihadapi oleh ibu nifas adalah ketika terjadi pada genitalia akibat persalinan sehingga ibu menahan untuk buang air kecil atau BAK (Gusrianty et al., 2016; Maryam, Hadi, \& Hapsari, 2013). Namun ibu masih memiliki kemampuan lain untu membuang cairan tubuh yaitu dengan mekanisme 
diaforesis (Rini \& D, 2017). Kedua mekanisme tersebut apabila tidak berjalan dengan lancar dapat mengakibatkan gangguan kesehatan pada ibu seperti infeksi saluran kencing (ISK) dan gangguan pada ginjal akibat produksi garam tubuh tidak dapat dikeluarkan oleh keringat serta sistem detoksifikasi tidak dapat berjalan (Aziz et al., 2009; Rohmah, 2011). Hal tersebut akan membuat ibu menghadapi permasalah kesehatan yang beragam yang memicu kejadian infeksi post partum selain permasalah yang sudah menyertai saat persalinan (Dalton \& Castillo, 2014; Rohmah, 2011).

Data di Swedia menunjukkan bahwa hampir sebanyak $20 \%$ ibu nifas mengalami infeksi post partum (Axelsson, 2019). Sebanyak 5-7\% ibu nifas yang mengalami infeksi post partum melahirkan dengan metode sectio caesaria (Dalton \& Castillo, 2014). WHO merilis angka sebanyak 15\% dari 500000 angka kematian ibu disebabkan oleh infeksi nifas (Chandra, 2016).

Ibu nifas perlu untuk menjaga kondisi karena dalam masa pemulihan dan rentan mengalami gangguan kesehatan (Lestari, 2016; Tulas, Kundre, \& Bataha, 2017). Perawatan tradisional dalam keluarga dapat menjadi salah satu cara menjaga kesehatan ibu nifas (Usman \& Sapril, 2018). Penelitian sebelumnya megungkapkan bahwa perawatan tradisional pada ibu nifas seperti perawatan yang menggunakan jamu, bengkung, bedaring, ramuan param dapat membantu merawat kesehatan ibu nifas (Fitrianti \& Angkasawati, 2015; Kamaruddin, Rawe, Asra, \& Marzuki, 2019; Usemahu, A.Rachman, \& Natsir, n.d.)

Penelitian menganai mandi uap secara tradisional telah dilaksanakan sebelumnya oleh masyarakat di Maluku dengan nama ba'ukup (Usemahu et al., n.d.). Perbedaan pada penelitian ini adalah masayarakat yang diambil sebagai sampel yaitu masyarakat Suku Muna dan daerah penelitian yaitu Kota Kendari Sulawesi Tenggara. Tujuan dari penelitian ini untuk mengeksplorasi perawatan etnocaring pada metode perawatan kesehatan pasca bersalin suku Muna menggunakan terapi tomboro atau mandi uap.

\section{METODE}

Penelitian ini adalah penelitian kualitiatif dengan pendekatan ethnografi. Sampel penelitian adalah dukun adat atau sando Suku Muna sebanyak 15 orang dengan partisipan triangulasi ibu nifas dari Suku Muna sebanyak 4 orang. Data dikumpulkan menggunakan teknik indepth interview dengan mengacu pada pedoman wawancara serta observasi partisipatori. Peneliti menggunakan field note untuk mencatat hasi observasi selama melaksanakan penelitian. Snowball sampling digunakan untuk mendapatkan sampel penelitian.

Trustiworthiness criteria dilaksanakan untuk mendapatkan keabsahan data. Pelaksanaan penelitian pada bulan juli sampai oktober 2019. Hasil penelitian dianilisi menggunakan aplikasi Nvivo 12 dengan teknik tematik analisis. Ethical clearance penelitian diberikan oleh IAKMI Pengurusa Daerah Sulawesi Tenggara dengan nomor 01/KEPK-IAKMI/V/2019.

\section{HASIL DAN PEMBAHASAN}

\section{Perawatan}

Tema perawatan diidentifikasi melalui kategori manfaat. Kategori manfaat digambarkan oleh kata kunci supaya melalui pernyataan sebagai berikut :

“...tomboro itu supaya cepat keluar keringat... kalau sakit kepala.... “(10)

"Saya kasikan lama itu supaya keringat keluar semua... ringan itu badan setelah itu ibu yang asinya tidak keluar bisa juga pakai tomboro, setelah ditomboro itu asinya langsung banyak..." (p11) 
... " ibu melahirkan tidak berkeringat itu tidak baik, begitumi saya ..... pakai tomboro untuk mereka yang sakit.... ambeyen yang habis dioperasi... supaya bisa kembalikan sehat lagi..." (p4)

"kalau pasien tidak rawat dirinya setelah sando selesaikan memandikan jadinya kuning... supaya sehat..." (p13)

"...supaya ringan itu badan..." (p15)

Kategori cara digambarkan oleh kata kunci uap, ditutup melalui pernyataan sebagai berikut :

"...baru orangnya duduk disampingnya baru ditutup pakai sarungta... " (p4)

“...dipakai, dihirup, ditaruhkan mukanya diatas asap...eee uapnya, lalu ditutupkan kain seperti selimut jadi badannya terkena semua sama uap... "(p11)

"...baru ditutup......" (p13)

\section{Perlengkapan}

Tema perawatan diidentifikasi melalui kategori bahan, alat dan cara. Kategori alat digambarkan oleh kata kunci batu, panci, sarung melalui pernyataan sebagai berikut :

"...tomboro itu caranya dibakarkan itu batu ... baru orangnya duduk disampingnya baru ditutup pakai sarungta 2 ta tiga dan duduk..." (p4)

"...ya tomboro dulu pake batu .... dibakar batu_kemudian itu habis dibakar itu batu_ditaruh di panci

.... baru kita hirup, tapi sekarang saya tidak pake batu..." (p9)

“... di mukanya begitu pakai sarung..."(p10)

“...kalau jaman dulu tomboro pakai batu, kalau sekarang pakai panci dimasakkan..." (p11)

“...pernah belajar caranya, caranya itu batu dibakar, ditaruhkan disamping pasien..." (p13)

"...orang tua dulu kasi tomboro, batu-batu dibakar...." (p15)

Kategori bahan digambarkan oleh kata kunci daun melalui pernyataan sebagai berikut :

“...biasanya daun pepaya dialaskan 7 daun, daun libo....jadi hawanya daun itu tidak keluar..." (p4)

"...isinya daun pepaya atau daun pisang yang kering direbus... " (p11)

"...rebus daun serei merah jahe sama kunyit juga... " (p19)

“...saya rebuskan daun pepaya... " (p10)

“...ada daunnya dia, daun pepaya yang 1 lembar sepotong sebelah, direbus baru ditutup... " (p13)

“...ditaruhkan daun kasape... “ (p15)

Pada interaksi alamiah sando dengan peneliti, sejumlah sando (P1, P2, P3, P5,P P6, P7, P8, P12, P14) dan partisipan triangulasi (PT1, PT2, PT3, PT4) menyatakan tidak pernah melakukan atau mendapatkan terapi tomboro namun partisipan sando pernah mengetahui terapi tersebut.

Peneliti tidak dapat melaksanakan observasi partisipatori pada ibu nifas karena pasien sando tidak ada yang memiliki indikasi untuk diberikan terapi tomboro. Namun, peneliti sempat mencoba untuk membuat dan menggunakan ramuan dauh sereh, jahe dan kunyit yang direbus kemudian digunakan dalam sungkup tomboro selimut sebagai pengganti sarung. 


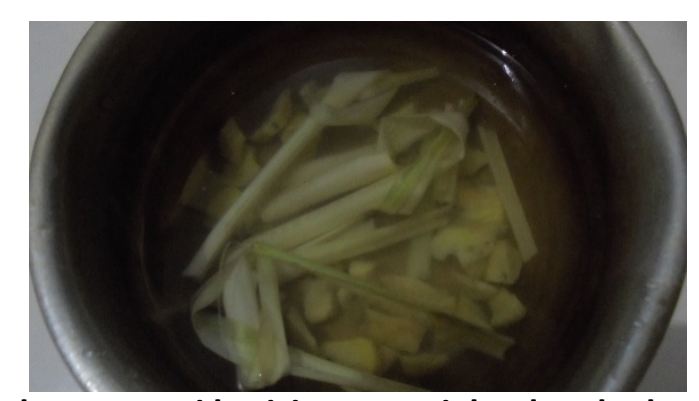

Gambar 1. Panci berisi ramuan jahe dan dauh sereh untuk tomboro sebelum direbus dengan kunyit
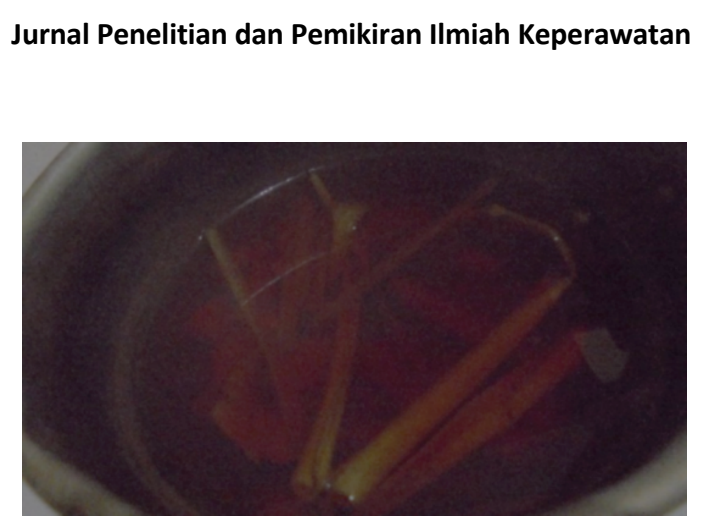

Gambar 2. Panci berisi ramuan jahe dan dauh sereh untuk tomboro setelah direbus dengan kunyit



Gambar 3. Tomboro

Penggunaan tomboro dengan alat selimut dan panci berisi ramuan berada di dalam selimut bersama dengan peneliti. Hasil maksimal apabila selimut dirapatkan ke lantai supaya suhu dan uap tidak keluar. Peneliti merasakan kesan suasana panas namun lembab karena uap air. Aroma rempah menyegarkan ketika dihirup dan terkena pada bagian wajah yang sengaja dihadapkan pada uap tomboro. Kesan yang peneliti dapatkan adalah menyegarkan dan menghangatkan badan.

Pemberian terapi Tomboro memiliki fungsi dan tujuan yang sama dengan mandi sauna yaitu untuk mengeluarkan keringat di dalam tubuh. Keringat yang diharapkan keluar membawa sisa metabolisme dan racun yang tidak terpakai lagi di dalam tubuh. Ibu nifas yang mengalami gangguan kesehatan akan merasa bugar dan sehat setelah melakukan terapi tomboro.

Pengeluaran keringat adalah salah satu proses alami dalam tubuh yang bermanfaat untuk menjaga kesetabilan metabolisme yaitu membuang sisa kelebihan cairan di dalam tubuh setelah kehamilan(Rini \& $D, 2017)$. Keringat dapat dirangsang pengeluarannya dengan menciptakan suasana atau suhu dengan panas melebihi dari suhu inti tubuh (Kukus, Supit, \& Lintong, 2013). Mandi uap membantu mengeluarkan keringat dan memiliki manfaat mengurangi stress, memperbaiki syaraf, sistem detoksifikasi serta memelihara kadar gula dalam darah (Rengganis, 2017). Penelitian sebelumnya mengenai pelaksanaan mandi uap menjelaskan bahwa memberikan efek rileks dan tekanan darah yang rendah dapat diperbaiki dengan terapi tersebut (Batubara, Ervizal, Hermawan, \& Umanggor, 2017; Polii, Rumampuk, \& Lintong, 2016) 
Pelaksanaan terapi tomboro pada jaman dahulu (yang dilakukan leluhur sando) menggunakan batu yang dibakar kemudian menempatkan dedaunan untuk menghasilkan panas yang berkhasiat. Sando yang berpartisipasi dalam penelitian memilih menggunakan metode lain yaitu merebus air dan memasukkan dedaunan yang dianggap berkhasiat yaitu daun pisang kering, daun belimbing, daun kasape, daun serai dan jahe.

Batu yang digunakan untuk mandi uap berfungsi sebagai pemanas untuk menghasilkan uap, improvisasi pelaksanaan tomboro dilakukan oleh sando pada masa kini dengan menggunakan rebusan air karena uap yang dihasilkan lebih banyak dan memiliki prinsip seperti penggunaan aromatherapy akibat dari penguapan kandungan daun yang digunakan dalam rebusan (Yogasara, 2014). Penelitian terdahulu yang meneliti manfaat penggunaan daun obat untuk mandi uap menjelaskan bahwa dedaunan tersebut dapat membantu memelihara kesehatan dan mencegah keluhan penyakit tertentu (Batubara et al., 2017). Daun libo yang digunakan oleh sando adalah daun fitofarmaka yang memiliki khasiat antioksidan dan antikanker (Cahyadi, Febrina, \& Rusli, 2016; Rijai, 2013).

Daun kasape dapat membersihkan darah kotor sebagiamana tujuan dari tomboro adalah membersihkan tubuh dari penyakit (Jumiarni, WO \& Komalasari, 2017). Daun pisang kering memiliki manfaat untuk menurunkan suhu tubuh dan memiliki kandungan antioksidan (Fadhilah \& Dewi, 2017). Daun belimbing yang dimaksud oleh sando adalah daun belimbing wuluh yang dapat menjadi obat tekanan darah tinggi(Jumiarni, WO \& Komalasari, 2017). Daun lain yang dipakai dalam mandi uap adalah daun pepaya dengan manfaat sebagai obat batu ginjal, jerawat, membersihkan darah dan hepatitis(Kharisma, 2013). Sereh dipercaya memiliki kandungan untuk menyembuhkan penyakit kuning, jahe dan kunyit digunakan untuk mengatasi gangguan pada kulit sekaligus sebagai antijamur, antiinflamasi dan antioksidan alami (Batubara et al., 2017; Jumiarni, WO \& Komalasari, 2017; Yuan Shan \& Iskandar, 2018)

\section{SIMPULAN DAN SARAN}

Penelitian ini menunjukkan manfaat tomboro pada ibu nifas dapat membantu mendapatkan kembali kebugarannya setelah kehamilan dan persalinan.terapi ini jarang dipraktikkan oleh sando karena kasus yang sangat jarang dijumpai. Adanya perubahan kebudayaan akibat interaksi yang terus menerus dari masyarakat dengan lingkungan baru yang memanfaatkan sumber daya dan kekuatan baru yang ada yaitu persediaan air, namun juga sando kehilangan sumber bahan alami sebagai ramuan dalam tomboro karena berada di lingkungan perkotaan. Perawatan berdasar pada budaya di Indonesia termasuk perawatan tomboro dari Suku Muna memililki manfaat yang baik untuk pemeliharaan kesehatan ibu nifas. Perawatan ini dapat digunakan oleh praktisi kesehatan sebagai salah satu terapi nonfarmakologi.

\section{UCAPAN TERIMA KASIH}

Peneliti mengucapkan terima kasih kepada Ditjen Penguatan Riset dan Pengembangan Kemenristekdikti yang telah memberikan pendanaan pada penelitian ini.

\section{DAFTAR PUSTAKA}

Axelsson, D. (2019). Postpartum Infections; Prevalence, Associated Obstetric Factors and the Role of Vitamin D. Linköping: LiU-Tryc.

Aziz, Fauzi, Sanif, \& Theodorus. (2009). Faktor risiko infeksi saluran kemih pada pertolongan persalinan spontan di RS Moh . Hoesin Palembang. Majalah Obstetri Ginekologi Indonesia, 33(1), 14-19. 
Batubara, R. P., Ervizal, A. M. Z., Hermawan, R. A., \& Umanggor, dan R. T. (2017). Nilai Guna Spesies Tumbuhan Dalam Oukup ( Mandi Uap) Masyarakat Batak Karo (Use Value Of Plant Spesies For Steam Bath Oukup, Karo ). Media Konservasi, 22(1), 79-86.

Cahyadi, D. D., Febrina, L., \& Rusli, R. (2016). Aktivitas Antioksidan Ekstrak Daun Libo (Ficus Variegate Blume) Dengan Berbagai Metode Ekstraksi. Nasional Tumbuhan Obat Indonesia Ke-50, (April), 2021.

Chandra, D. (2016). Puerperal sepsis. Retrieved November 10, 2019, from Disease website: https://www.nhp.gov.in/disease/gynaecology-and-obstetrics/puerperal-sepsis

Dalton, E., \& Castillo, E. (2014). Post partum infections: A review for the non-OBGYN. Obstetric Medicine, 7(3), 98-102. https://doi.org/10.1177/1753495X14522784

Danefi, T. (2016). Gambaran Efektifitas Asuhan Dalam Kunjungan Masa Nifas Dan Ketidaknyamanan Fisik Dalam Masa Nifas Di Desa Cikunir Kecamatan Singaparna Kabupaten Tasikmalaya Tahun 2016. Jurnal Bidkesmas, 2(7), 51-55.

Fadhilah, E., \& Dewi, A. U. (2017). Teh Klaras Sebagai Minuman Menyehatkan. Majalah Farmasetika, 2(5), 14. https://doi.org/10.24198/farmasetika.v2i5.16781

Fauzia, S., \& Sutejo. (2012). Keperawatan Maternitas Kehamilan - Vol. 1. Jakarta: Kencana.

Fitrianti, Y., \& Angkasawati, J. (2015). Pengobatan Tradisional Gayo untuk Ibu Nifas. Buleitin Penelitian Sistem Kesehatan, 18(2), 111-119.

Gusrianty, A. R., Astuti, S., Hartinah, H., \& Susanti, A. I. (2016). Angka Kejadian Gejala Infeksi Saluran Kemih Pada Ibu Hamil Di Desa Mekargalih Kecamatan Jatinangor Kabupaten Sumedang Tahun 2014. Jurnal Sistem Kesehatan, 1(2), 71-75. https://doi.org/10.24198/jsk.v1i2.10347

Jumiarni, WO \& Komalasari, O. (2017). Eksplorasi Jenis dan Pemanfaatan Tumbuhan Obat Pada Masyarakat Suku Muna di Permukiman Kota Wuna. Traditional Medicine Journal, 22(April), 45-56.

Kamaruddin, M., Rawe, A. D. T., Asra, A., \& Marzuki, I. (2019). Kepercayaan Terhadap Kemampuan Budaya Bengkung dalam Meningkatkan Produksi Air Susu lbu Pada Masyarakat Bulukumba. Eksplorasi Sumberdaya Alam Hayati Indonesia Berbasis Entrepreneurship Di Era Revolusi Industri 4.0, 476-479. Makassa.

Kharisma, Y. (2013). Tinjauan Pemanfaatan Tanaman Pepaya dalam Kesehatan. Universitas Islam bandung.

Kukus, Y., Supit, W., \& Lintong, F. (2013). Suhu Tubuh: Homeostasis Dan Efek Terhadap Kinerja Tubuh Manusia. Jurnal Biomedik (Jbm), 1(2). https://doi.org/10.35790/jbm.1.2.2009.824

Lestari, P. (2016). Usia Berpengaruh Dominan Terhadap Perilaku Perawatan Luka Perineum pada Ibu Nifas di RSUD Sleman. Jurnal Ners Dan Kebidanan Indonesia, 4(2), 95. https://doi.org/10.21927/jnki.2016.4(2).95-101 
Maryam, Y., Hadi, P., \& Hapsari, R. (2013). Pengaruh Mode Persalinan Terhadap Kejadian Infeksi Saluran Kemih Postpartum. Jurnal Media Medika Muda, 2(1).

Polii, S., Rumampuk, J. F., \& Lintong, F. (2016). Pengaruh mandi uap terhadap tekanan darah pada wanita dewasa normal. Jurnal E-Biomedik, 4(1), 141-145. https://doi.org/10.35790/ebm.4.1.2016.10857

Rengganis, D. (2017). BOOK OF SAUNA : UNGKEP SIMUR KURUNG. Yogyakarta.

Rijai, L. (2013). Potensi tumbuhan Libo (Ficus variegata, Blume) sebagai Sumber Bahan Farmasi Potensial. Journal Of Tropical Pharmacy And Chemistry, 2.

Rini, S., \& D, F. K. (2017). Panduan Asuhan Nifas dan Evidence Based Practice. Yogyakarta: Deepublish.

Rohmah, N. (2011). Manajemen Nyeri Non Invasive Pada Ibu Post Partum Dengan Pendekatan Evidence Based Practice. Jurnal Ners, 6(2), 201-209.

Tulas, V. D. P., Kundre, R., \& Bataha, Y. (2017). Hubungan Perawatan Luka Perineum Dengan Perilaku Personal Hygiene Ibu Post Partum Di Rumah Sakit Pancaran Kasih Gmim Manado. Jurnal Keperawatan, 5(1).

Usemahu, K. M., A.Rachman, W., \& Natsir, S. (n.d.). Perilaku Penggunaan Obat Tradisional pada Ibu Pasca Melahirkan di Desa Kailolo Kabupaten Maluku Tengah.

Usman, U., \& Sapril, S. (2018). Pemanfaatan Budaya Posoropu dalam Perawatan Masa Nifas oleh Perempuan Buton Utara. Media Kesehatan Masyarakat Indonesia, 14(3), 268. https://doi.org/10.30597/mkmi.v14i3.4453

Yogasara, T. (2014). Pengaruh Jenis Musik Dan Aromaterapi Terhadap Kemampuan Kognitif Mahasiswa Untuk Tiap Tipe Kepribadian. Universitas Katolik Parahyangan.

Yuan Shan, C., \& Iskandar, Y. (2018). Studi Kandungan Kimia Dan Aktivitas Farmakologi Tanaman Kunyit (Curcuma longa L.). Farmaka, 16(2), 547-555. 